\title{
Model Organizma Galleria mellonella'da Hemolenf ve Dokudan Düşük Maliyetli ve Basit DNA İzolasyon Metodu
}

\author{
Emre GÜLSU ${ }^{1 *} \quad$ Tamer KAYIŞ $^{1} \quad$ Mustafa COŞKUN $^{1}$ \\ ${ }^{1}$ Adıyaman Üniversitesi, Fen-Edebiyat Fakültesi, Biyoloji Bölümü, Adıyaman.

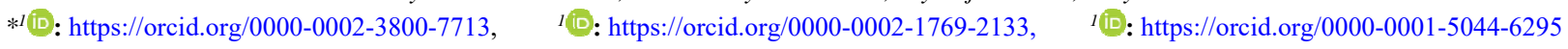

Öz: Bu çalışmada, geleneksel laboratuvar çalışmalarında sıklıkla kullanılan ve ekonomik olan kimyasallar ile sarf malzemelerinden faydalanılarak, polimeraz zincir reaksiyonu (PZR) işlemlerinde kullanılmak üzere dokulardan ve vücut sıvılarından, mevcut DNA izolasyon yöntemlerine alternatif bir gDNA izolasyon yöntemi oluşturmak amaçlanmıştır. Bu amaçla model organizma olarak Galleria mellonella L. (Lepidoptera: Pyralidae) kullanılmıştır. Çalışmada, oluşturduğumuz yöntemle karş̧laştırma yapabilmek için iki farklı DNA izolasyon yöntemi de uygulanmıştır. İzolasyonu yapılan DNA' ların miktar ve saflığ $260 \mathrm{~nm}$ ve $260 \mathrm{~nm} / 280 \mathrm{~nm}$ ' de spektrofotometrik ölçümlerle belirlenmiş ve agaroz jel elektroforezi ile kontrolleri yapılmıştır. Fenolsüz ve santrifüjsüz yöntem, InstaGene matrix yöntemi ve bazı modifikasyonlar yaparak oluşturduğumuz DNA izolasyon yöntemi ile hemolenf örneğinden elde edilen $\mathrm{A}_{260}$ değerleri sirasıyla 0,032, 0,157, 0,432; doku örneğinden elde edilen $\mathrm{A}_{260}$ değerleri ise sirasıly 0,291, 0,121, 0,346 bulunmuştur. Saflık değerleri ise hemolenf grubunda sirasıyla 1,030, 1,401, 1,878; doku grubunda ise 1,785, 1,690, 2,011 olarak tespit edilmiştir.

Sonuç olarak modifiye edilerek oluşturduğumuz yöntem ile hem vücut sıvısından hem de dokudan yeterli miktar ve kalitede DNA elde edilebildiği tespit edilmiştir.

\section{Simple and Cost-efficient DNA Isolation Method from Hemolymph and Tissue of Model Organism Galleria mellonella}

Abstract: The aim of this work is to produce a cost-efficient gDNA isolation method from tissue and body fluid as an alternative to current isolation protocols by using economic chemicals and materials that are often used in routine laboratory studies for use in a polymerase chain reaction (PCR). For this purpose, Galleria mellonella L. (Lepidoptera: Pyralidae) was used as a model organism. In this study, both of the two different DNA isolation methods were applied to compare our developed method. The concentration and purity of the obtained DNA were determined by measuring the purity spectrophotometrically at $260 \mathrm{~nm}$ and $260 \mathrm{~nm} / 280 \mathrm{~nm}$ and validated by agarose gel electrophoresis. Absorbances at $260 \mathrm{~nm}$ obtained from the hemolymph by the method of DNA isolation which was carried without phenol and centrifugation, InstaGene matrix method, and the method developed by us were $0.032,0.157,0.432$ respectively. The $\mathrm{A}_{260}$ results of the isolated DNA obtained from tissue samples were as $0.291,0.121$, and 0.346 in respect to the DNA isolation methodologies. The purity of DNA from hemolymph and tissue were 1.030, 1.401, 1.878 and 1.785, 1.690, 2.011 respectively.

As a result, in a sufficient amount and quality gDNA was obtained from both the body fluid and tissue by the method that has been developed. 


\section{GİRIŞ}

Moleküler biyolojide ilk basamak olarak tanımlanan genomik DNA' nın saf ve yeterli miktarda elde edilebilmesi daha sonraki basamakların başarılı bir şekilde yapılabilmesi için elzemdir. Bunun için hücrenin parçalanması, protein ve yağ kirliliğinin uzaklaştırılması ve DNA' nın çöktürülerek saflaştırılması gibi basamaklar izlenir. Hücre zarı fosfolipidlerini denatüre etmek için çeşitli anyonik deterjanlar kullanılırken, proteinlerin parçalanması için ise sıklıkla Proteinaz K gibi çeşitli proteaz enzimler kullanılır (Bailes vd., 2007).

Parçalanan proteinlerin ortamdan uzaklaştırılmasında ise genellikle güçlü bir denatürasyon ajanı olan fenol kullanılmaktadır (Lahiri vd., 1992). Ancak fenolün çevre ve insan sağlığı açısından zararlı etkilerinden dolayı alternatif denatürasyon ajanları için çeşitli çalışmalar yapılmaktadır (Bozkaya, 2012; Lahiri vd., 1992). Proteinleri uzaklaştırılan çözeltideki DNA izopropanol ile çöktürülerek saflaştırılabilir (Sambrook vd., 1989). DNA izolasyonunda çeşitli manuel yöntemlerin yanı sıra yüksek maliyetli hazır DNA izolasyon kitleri de kullanılmaktadır.

$\mathrm{Bu}$ çalışmada, rutin laboratuvar çalışmalarında sıklıkla kullanılan ve ekonomik olan kimyasalları kullanarak mevcut izolasyon yöntemlerine alternatif, dokudan ve vücut sıvılarından gDNA izolasyonu yöntemi oluşturmak amaçlanmıştır. $\mathrm{Bu}$ amaçla, hızlı yaşam döngüsü, larva büyüklüğü ve yapay besinlerle kolay olarak üretilebilmesi nedeniyle birçok fizyolojik, immünolojik, biyokimyasal ve parazitolojik çalışmalarda model organizma olarak kullanılan Galleria mellonella L. (Lepidoptera: Pyralidae) (Emre vd., 2013; Kayis vd., 2015) kullanılmıştır.

Böcekler açık dolaşım sistemine sahip oldukları için omurgalılardaki gibi kan ve lenfatik sıvıların ayrımı yoktur ve vücut sıvıları hemolenf olarak adlandırılmaktadır (Rowley ve Ratcliffe, 1981). Böceklerdeki immün sisteminin memelilerle olan benzerliği (Strand, 2008; Zasloff, 2002) ortaya konduktan sonra immün yanit ve patojenite çalışmalarında (Ponnuvel ve Yamakawa, 2002), antimikrobiyal peptid çalışmalarında (Mak vd., 2010; Cytrynska vd., 2007) ve genom çalışmalarında (Kim vd., 2004) model organizma olarak kullanılması önemli ölçüde artmıştır.

Literatürde G. mellonella' dan DNA izolasyonu ile ilgili çeşitli çalışmalar mevcuttur. Mukherjee vd., (2010) Listeria patojenitesini ortaya koydukları çalışmada $G$. mellonella' nın hemolenfinden hazır kit ile DNA izolasyonunu gerçekleştirmişlerdir. Cherepenko vd., (1982) G. mellonella' nın hücre çekirdeğinden DNA elde etmede kullandıkları yöntemin fenol metoduna göre daha yüksek verimle çalıştığını söylemişlerdir. Nale vd., (2016) Clostridium difficile patojen enfeksiyonunu araştırdıkları çalışmalarında model organizma olarak kullandıkları G. mellonella hemolenfinden ticari kit yardımıyla DNA izolasyonunu gerçekleştirmişlerdir. Barwise ve Walker
(1970) ise G. mellonella' dan Galleria virüsü DNA' sını izole etmede fenol ekstraksiyon yöntemini kullanmışlardır. Wagley vd., (2018) Vibrio parahaemolyticus virulansinda G. mellonella' nın model organizma olarak kullanılabileceğini gösterdikleri çalışmalarında G. mellonella' dan DNA izolasyonunu vücut sivisından ticari kit ile gerçekleştirmişlerdir.

Daha önce yapılan çalışmalarda G. mellonella' da DNA izolasyonunda genellikle hemolenften izolasyon yapılmış ve hazır izolasyon kitleri ve fenol-kloroform yöntemleri kullanılmıştır. Sunulan çalışmada öncelikle böceğin hemolenfinin yanı sira dokudan da izolasyonu gerçekleştiren, ticari kitlere göre maliyeti daha ucuz olan bir yöntem geliştirmek ve uygulamak amaçlanmıştır.

\section{MATERYAL ve METOT}

\section{DNA İzolasyonu için Galleria mellonella} Bireylerinin Hazırlanması: DNA izolasyonu için G. mellonella bireylerinin taze doku ve hemolenfi kullanılmıştır. Stok G. mellonella bireyleri, $30 \pm 2{ }^{\circ} \mathrm{C}$ ve $\% 75 \pm 5$ bağ 1 neme sahip, 24 saat karanlık fotoperiyodu uygulanan laboratuvar koşullarında Bronskill (1961) tarafından gösterilen besin ile yetiştirilen $G$. mellonella larvalarından elde edilmiştir. Çalışmalarda yaklaşık 250-300 mg ağırlığındaki son evre larvaları kullanılmıştır. Doku örnekleri, 2 adet canlı son dönem larvası ezilerek dondurulmadan doğrudan işleme alınmıştır. Hemolenf örneklerinin elde edilmesi için ise önce böcekler $4{ }^{\circ} \mathrm{C}$ ' de 15 dakika bekletilerek hareketsiz kalmaları sağlanmış ve vücut yüzeyleri \% 70 etanol ile sterilize edilmiştir. Hemolenf örnekleri, larvanın 1. abdomen bacak segmentinin dip kısmına steril lanset batırılarak alınmış ve melanizasyonu önlemek için hemen feniltiyoüre kristalleri içeren soğutulmuş steril ependorf tüplerine aktarılarak dondurulmadan işleme alınmıştır (Cytrynska vd., 2007).

Genomik DNA izolasyonu: Doku ve vücut sıvısından genomik DNA izolasyonu için üç farklı protokol uygulanmıştır. Bunlar; fenolsüz ve santifüjsüz DNA izolasyon yöntemi (Laird vd., 1991) (protokol 1), InstaGene Matrix ile DNA izolasyon yöntemi (Bio-rad, 2018) (protokol 2) ve Sambrook vd., (1989) tarafından tanımlanmış fenolkloroform ekstraksiyonu yönteminin modifiye edilmesi ile geliştirdiğimiz yöntem (protokol 3) dir.

Fenolsüz ve Santrifüjsüz DNA İzolasyon Yöntemi: Laird vd., (1991) yönteminden uyarlanmıştır. Bu yöntemde dokudan izolasyonda $0,5 \mathrm{~mL}$ liziz buffer (100 mM Tris- $\mathrm{HCl}$, pH 8,5 - $5 \mathrm{~mL}$; 0,5 M EDTA - 0,5 mL; \% 10 SDS - $1 \mathrm{~mL} ; 5$ $\mathrm{M} \mathrm{NaCl}-2 \mathrm{~mL} ; 20 \mathrm{mg} / \mathrm{mL}$ Proteinaz K - 0,25 mL) konarak son hacim $50 \mathrm{~mL}$ olacak şekilde distile su ile tamamlanmıştır. Dokular $55^{\circ} \mathrm{C}$ ' de 1-2 saatte çalkalanarak parçalanmış, oluşan lizata bir hacim izopropanol eklenerek 10 dakika vortekslenmiştir. DNA' nın verimli olarak 
alınabilmesi için pipet ucu yardımıyla toplanan çökelti uzaklaştırılmıştır. DNA içerisinde $250 \mu \mathrm{L}(10 \mathrm{mM}$ Tris $\mathrm{HCl}$, 0,1 mM EDTA, pH 7,5) içeren mikrosantrifüj tüplerine konulmuş ve tam olarak çözünmesi için $55^{\circ} \mathrm{C}$ ' de bir saat çalkalama işlemine tabi tutulmuştur.

InstaGene Matrix Yöntemi: Böcekler 1,5 mL' lik mikrosantrifüj tüplerine alınarak üzerlerine her bir örnek için $100 \mu \mathrm{L} 1 \mathrm{x}$ PBS eklenmiş hafifçe ezilmiştir, daha sonra üzerine $200 \mu \mathrm{L}$ InstaGene Matrix eklenmiştir. Böceğin iyice parçalandığından emin oluncaya kadar PBS ve InstaGene Matrix işlemleri sırasıyla tekrar edilmiştir. Parçalanan örnekler 30 saniye vortekslendikten sonra 10 dakika $99^{\circ} \mathrm{C}^{\prime}$ de sicak su banyosunda tutulmuştur. İnkübasyondan sonra 12000 rpm' de 10 dakika santrifüj edilen örneklerden $100 \mu \mathrm{L}$ süpernatant alınmış ve $-20^{\circ} \mathrm{C}$ ' de saklanmıştır (Bio-rad Laboratories, 2018).

Modifiye Edilerek Geliştirilen DNA İolasyon Yöntemi: Dokudan izolasyon için, böcekler ezilerek 1,5 mL' lik ependorf tüplerine, hemolenften izolasyon için ise $20 \mu \mathrm{L}$ kadar hemolenf örneği alınıp 1,5 mL'lik ependorf tüplerine konulmuştur. Üzerine $500 \mu \mathrm{L}$ 1x SSC tamponu ilave edilerek vortekslenenen tüpler 2 dakika 12000 rpm'de santrifüj edilmiştir. Süpernatant uzaklaştırılmış ve bu işlem bir kez daha tekrar edilmiştir. Tüplerin üzerlerine önce $100 \mu \mathrm{L} 0,2 \mathrm{M}$ $\mathrm{NaOAc}$ ilave edilerek vortekslenmiş daha sonra $10 \mu \mathrm{L} \% 10$, luk SDS ve $5 \mu \mathrm{L}$ proteinaz $\mathrm{K}(20 \mathrm{mg} / \mathrm{mL})$ eklenip çalkalanmış ve $55^{\circ} \mathrm{C}^{\prime}$ de 30 dakika inkübe edilmiştir. $100 \mu \mathrm{L}$ fenol-kloroform-izoamil alkol (25:24:1) eklenerek 30 saniye vortekslenenen tüpler, sonrasında 5 dakika 12000 rpm' de santrifüj edilmiştir. Oluşan üç farklı fazdan üstteki faz ependorf tüpüne alınmış ve üzerine $20 \mu \mathrm{L} 2 \mathrm{M} \mathrm{NaOAc}$ ve $300 \mu \mathrm{L} \% 100$ etanol (soğutulmuş) konulup vortekslendikten sonra $-20^{\circ} \mathrm{C}$ 'de 10 dakika bekletilmiştir. $\mathrm{Bu}$ süre sonunda örnekler 12000 rpm'de 1 dakika santrifüj edilerek süpernatant uzaklaştırılmış ve $500 \mu \mathrm{L} \% 70$ etanol eklenerek 1 dakika daha 12000 rpm'de santrifüj edilmiştir. Tüpte kalan pellet 15 dakika kurutulmuş ve üzerine $100 \mu \mathrm{L}$ TE tamponu ilave edildikten sonra vortekslenerek $55^{\circ} \mathrm{C}$ 'de bir gece inkübe edilmiştir.

\section{DNA Örneklerinin Saflk ve Miktar Tayini:} İzolasyonu yapılan DNA örneklerinin kontrolü jel elektroforezinde yürütülerek yapılmıştır. Bunun için \% 1 agaroz jel elektroforezi kullanılmıştır. Elde edilen gDNA' nın miktarının belirlenmesi için spektrofotometre ile $260 \mathrm{~nm}$ ' de, saflığının belirlenmesi için ise 260/280 nm' deki absorbans oranı ile belirlenmiştir. Elde edilen DNA çözeltisi distile su ile 1/10 oranında seyreltilmiştir. DNA konsantrasyonu (DNA konsantrasyonu $(\mu \mathrm{g} / \mathrm{mL})=$ OD $260 \times 50 \mu \mathrm{g} / \mathrm{mL} \times$ dilüsyon faktörü) hesaplanmıştır (Sambrook vd., 1989).

\section{SONUÇ ve TARTIŞMA}

G. mellonella' nın doku ve hemolenfinden izolasyon yöntemiyle elde edilen gDNA'lar \% 1'lik agaroz jelde yürütülmüştür (Şekil 1). Spektrofotometrede $260 \mathrm{~nm}$ deki absorbans değerleri ve saflık dereceleri $\left(\mathrm{A}_{260} / \mathrm{A}_{280}\right)$ Tablo 1'de gösterilmiştir.

Tablo 1. DNA konsantrasyonları ve saflı̆̆ını belirten absorbans değerleri.

\begin{tabular}{lllllll}
\hline & \multicolumn{3}{c}{ Absorbans (260) } & \multicolumn{3}{c}{ Absorbans (A 260/A280) } \\
\hline Örnek & Pr1 & Pr2 & Pr3 & Pr1 & Pr2 & Pr3 \\
\hline Hemolenf & 0,032 & 0,157 & 0,432 & 1,030 & 1,401 & 1,878 \\
Doku & 0,291 & 0,121 & 0,346 & 1,785 & 1,690 & 2,011 \\
\hline Pr1: Fenolsüz ve santifüjsüz DNA & izolasyon yöntemi (Laird vd., 1991), \\
Pr2: InstaGene Matrix ile DNA izolasyon yöntemi (Bio-rad, 2018), \\
Pr3: Modifiye edilerek geliş̧tirdiğimiz yöntem.
\end{tabular}

Protokol 1 ile izole edilen DNA'nın hemolenf örneğinin saflık derecesi ( $\mathrm{A}_{260} / \mathrm{A}_{280}$ oran1) 1,03 bulunmuştur. Bu değer Sambrook vd., (1989) belirttiği saf DNA oranının $(1,8-2,2)$ altındadır. DNA miktarı, spektrofotometrik olarak belirlenebilmesine rağmen bu değer oldukça az olduğundan ( $\left.\mathrm{A}_{260}: 0,032 ; 16 \mu \mathrm{g} / \mathrm{mL}\right)$ agaroz jelde görüntülenememiştir. Aynı yöntemle dokudan yapılan izolasyonda ise örneğin 260 nm deki absorbansı 0,291, saflığı da 1,8 olarak bulunmuştur. Bu yöntemi Laird vd., (1991) memeli doku ve hücresini kullanarak uygulamış ve büyük doku örneği gerektirmesi, liziz sırasında yetersiz çökelme, DNA'nın az çözülmesi gibi olumsuzluklara rağmen fenol-kloroform izolasyon yöntemine alternatif olarak kullanılabileceğini göstermiştir. Sunulan çalışma bu protokolün doku örneğinden DNA izolasyonunda daha iyi sonuç verdiğini göstermiştir.

InstaGene Matrix yöntemi ile hemolenften izole edilen DNA miktarı $\left(\mathrm{A}_{260}: 0,157 ; 78,5 \mu \mathrm{g} / \mathrm{mL}\right)$ olarak tespit edilmiş ancak jel elektroforezinde görüntülenememiştir (Şekil 1). Elde edilen saflık oranı da $\left(A_{260} / A_{280}: 1,401\right)$ düşüktür. Bunun yanında dokudan izolasyonda saf DNA miktarına çok yakın bir DNA elde edilmiştir. Strøm vd., (2014) InstaGene Matrix ile kuru kandan da DNA elde edilebildiğini göstermişlerdir.

Sambrook vd., (1989) fenol-kloroform yöntemi temelinde geliştirip uyguladığımız yöntemde elde edilen gDNA örneklerinin agaroz jel görüntüleri (Şekil 1) ve UV spektrofotometre absorbans değerleri (Tablo 1) gerekli standartlara uygun bulunmuştur.

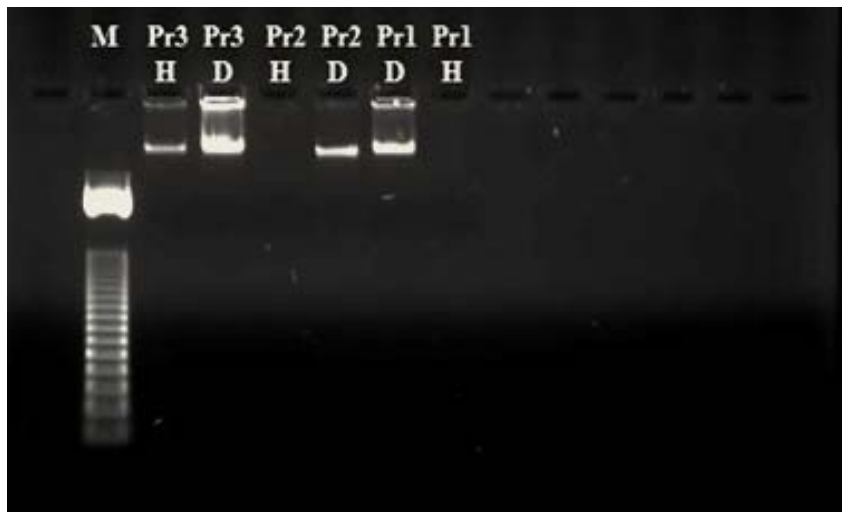

Şekil 1. Galleria mellonella'ya ait gDNA'nın agaroz jel elektroforezi görüntüleri (M. Marker, Pr. Protokol, H. Hemolenf, D. Doku) 
Örneklerin absorbans değerleri ölçüldüğünde $\mathrm{A}_{260} / \mathrm{A}_{280}$ oranının hem doku $(2,011)$ hem de hemolenf $(1,878)$ için saf DNA değerinde olduğu tespit edilmiştir ve jel fotoğraflama ile net bir bant elde edilmiştir (Şekil 1).

Gerek jel görüntüsü gerek spektrofotometre ölçümleri bize elde edilen DNA'nın saf ve miktarının yeterli olduğunu göstermektedir.

Sonuç olarak geliştirdiğimiz yöntemin $G$. mellonella'dan DNA izolasyonunda kullanılabileceği belirlenmiştir. Laboratuvarda sıklıkla kullanılan, dolayısıyla kullanıcı açısından ulaşımı kolay olan kimyasallar, sarf malzemeler ve teknik ekipmanlarla yapılması, hem dokudan hem de vücut sıvısından izolasyonun gerçekleştirilebilmesi, yoğun DNA miktarı gerektiren çalışmalar için uygun olması ve daha az maliyet gerektirmesi yöntemin olumlu yanlarını oluştururken, diğer protokollere göre izolasyonun daha uzun sürmesi yöntemin tek dezavantajıdır. Yöntemin farklı organizmalarla daha çok sayıda örnek kullanılarak denenmesi, uygulanabilirliğinin ve başarısının arttırılmasında faydalı olacaktır.

\section{KAYNAKLAR}

Bailes, S.M., Devers, J.J., Kirby, J.D. \& Rhoads, D.D. (2007). An inexpensive, simple protocol for DNA isolation from the blood for high-throughput genotyping by polymerase chain reaction or restriction endonuclease digestion. Poultry Science, 86(1), 102-106. Doi: 10.1093/ps/86.1.102.

Barwise, A.H. \& Walker, I.O. (1970). Studies on the DNA of a virüs from Galleria mellonella. Febs Letters, 6(1), 13-16. Doi: 10.1016/0014-5793(70)80028-X.

Bio-rad laboratories (2018). Insta Gene Matrix: Prepare DNA templates for PCR with no phenol/chloroform extractions and no deproteinization steps. Tech note 1810. Erişim Tarihi: 05.04.2018.

Bozkaya, F. (2012). DNA izolasyonunda Fenol-Kloroform yerine Potasyum-Asetat kullanımının DNA miktarı ve kalitesine etkisi”, Harran Üniversitesi Veteriner Fakültesi Dergisi, 1(2), 92-96.

Bronskill, J.K. (1961). A cage to simplify the rearing of greater wax moth, Galleria mellonella (Pyralidae). Journal of Lepidopterist's Society, 15(2), 102-104.

Chen, H.M., Wang, W., Smith, D. \& Chan, S.C. (1997). Effects of the antibacterial peptide cecropin $\mathrm{B}$ and its analogs, cecropins B-1 and B-2, on liposomes, bacteria, and cancer cells. Biochimica et Biophysica Acta, 1336(2), 171-179. Doi: 10.1016/S03044165(97)00024-X.

Cherepenko, E.I., Galkin, A.P., Lebedev, V.R. \& Kok, I.P. (1982). A non-damaging procedure for DNA isolation from insect cell nuclei. Ukrainian Biochemical Journal, 54(3), 316-321.

Cytrynska, M., Mak, P., Zdybicka-Barabas, A., Suder, P. \& Jakubowicz, T. (2007). Purification and characterization of eight peptides from Galleria mellonella immune hemolymph. Peptides, 28(3), 533-546. Doi: 10.1016/j.peptides.2006.11.010.

Cytrynska, M., Zdybicka-Barabas, A., Jablonski, P. \& Jakubowicz, T. (2001). Detection of antibacterial polypeptide activity in situ after sodium dodecyl sulfate-polyacrylamide gel electrophoresis. Analytical Biochemistry, 299(2), 274-276. Doi: 10.1006/abio.2001.5422.

Emre, I., Kayis, T., Coskun, M., Dursun, O. \& Cogun, H.Y. (2013). Changes in antioxidative enzyme activity, glycogen, lipid, protein, and malondialdehyde content in cadmium-treated Galleria mellonella larvae. Annals of the Entomological Society of America, 106(3), 371-377. Doi: 10.1603/AN12137.

Kayis, T., Coskun, M., Dursun, O. \& Emre, I. (2015). Alterations in antioxidant enzyme activity, lipid peroxidation and ion balance induced by Dichlorvos in Galleria mellonella L. Annals of the Entomological Society of America, 108(4), 570-574. Doi: 10.1093/aesa/sav038.

Kim, C.H., Lee, J.H., Kim, I., Seo, S.J., Son, S.M. \& Lee, K.Y. (2004). Purification and cDNA cloning of a cecropin-like peptide from the great wax moth, Galleria mellonella. Molecules and Cells, 17(2), $262-266$

Lahiri, D.K., Bye, S., Nurnberger, J.I., Hodes, M.E. \& Crisp, M. (1992). A non-organic and non-enzymatic extraction method gives higher yields of genomic DNA from whole-blood samples than do nine other methods tested. Journal of Biochemical and Biophysical Methods, 25(4), 193-205. Doi: 10.1016/0165-022X(92)90014-2.

Laird, P.W., Zijderveld, A., Linders, K., Rudnicki, M.A., Jaenisch, R. \& Berns, A. (1991). Simplified mammalian DNA isolation procedure. Nucleic Acids Research, 19(15), 4293.

Lamberty, M., Ades, S., Uttenweiler-Joseph, S., Brookhart, G., Bushey, D., Hoffmann, J.A. \& Bulet, P. (1999). Insect immunity. Isolation from the lepidopteran Heliothis virescens of a novel insect defensin with potent antifungal activity. Journal of Biological Chemistry, 274(14), 9320-9326. Doi: 10.1074/jbc.274.14.9320.

Mak, P., Zdybicka-Barabas, M. \& Cytynska, A. (2010). A different repertoire of Galleria mellonella antimicrobial peptides in larvae challenged with bacteria and fungi. Developmental \& Comparative Immunology, 34(10), 1129-36. Doi: 10.1016/j.dci.2010.06.005.

Mukherjee, K., Altincicek, B., Hain, T., Domann, E., Vilcinskas, A. \& Chakraborty, T. (2010). Galleria mellonella as a model system for studying Listeria pathogenesis. Applied and Environmental Microbiology, $\quad \mathbf{7 6}(1), \quad 310-317 . \quad$ Doi: 10.1128/AEM.01301-09.

Nale, Y.J., Chutia, M., Carr, P., Hickenbotham, P.T. \& Clokie, M.R.J. (2016). Get in early: Biofilm and wax moth (Galleria mellonella) models reveal new insights into the therapeutic potential of Clostridium difficile bacteriophages. Frontiers in Microbiology, 7, 1383. Doi: 10.3389/fmicb.2016.01383.

Ponnuvel, K.M. \& Yamakawa, M. (2002). Immune responses against bacterial infection in Bombyx mori and regulation of host gene expression. Current Science, 83(4), 447-454. 
Rowley, A.F. \& Ratcliffe, N.A. (1981). Insects, In: Ratcliffe NA, Rowley AF (Ed), Invertebrate Blood Cells, 2nd ed., 421-488 p. Academic Press, London,

Sambrook, J., Fritsch, E.F. \& Maniatis, T. (1989). Molecular Cloning: A laboratory manual, Cold Spring Harbor Laboratory Press. New York.

Strand, M.R. (2008). The insect cellular immune response. Insect Science, 15, 1-14. Doi: 10.1111/j.17447917.2008.00183.x.

Strøm, G.E.A., Tellevik, M.G., Hanevik, K., Langeland, N. \& Blomberg, B. (2014). Comparison of four methods for extracting DNA from dried blood on filter paper for PCR targeting the mitochondrial Plasmodium genome. Transactions of The Royal Society of Tropical Medicine and Hygiene, 108(8), 488-94. Doi: 10.1093/trstmh/tru084.

Wagley, S., Borne, R., Harrison, S., Baker-Austin, C., Ottaviani, D., Leoni, F., Vuddhakul, V. \& Titball, R.W. (2018). Galleria mellonella as an infection model to investigate the virulence of Vibrio parahaemolyticus. Virulence, 9(1), 197-207. Doi: 10.1080/21505594.2017.1384895.
Zasloff, M. (2002). Antimicrobial peptides of multicellular organisms. Nature, 415(6870), 389-395. Doi: 10.1038/415389a.

\section{*Corresponding author's:}

Emre GÜLSU

Adres. Adıyaman Üniversitesi, Fen Edebiyat Fakültesi, Biyoloji Bölümü, Adryaman, Türkiye

\E-mail: emregulsu84@gmail.com

ORCID: https://orcid.org/0000-0002-3800-7713 